\title{
Study on Drying of Black Rice (Oryza sativa L.) Grains: Physical-Chemical and Bioactive Quality
}

\author{
N. C. Santos ${ }^{1}$, W. P. Silva ${ }^{1}$, S. L. Barros ${ }^{1}$, A. J. de B. Araújo ${ }^{1}$, J. P. Gomes ${ }^{1}$, R. L. J. Almeida ${ }^{1}$, \\ A. P. S. Nascimento ${ }^{1}$, R. D. Almeida ${ }^{1}$, C. M. D. P. S. e Silva ${ }^{1}$, A. J. M. Queiroz ${ }^{1} \&$ R. M. F. Figueiredo ${ }^{1}$ \\ ${ }^{1}$ Federal University of Campina Grande, Campina Grande, PB, Brazil \\ Correspondence: W. P. Silva, Physics Department, Federal University of Campina Grande, R. Aprígio Veloso, \\ 882, Campina Grande, PB, Brazil. E-mail: wiltonps@uol.com.br
}

Received: March 30, 2019

doi:10.5539/jas.v11n9p203

\author{
Accepted: April 30, 2019 Online Published: June 30, 2019 \\ URL: https://doi.org/10.5539/jas.v11n9p203
}

\begin{abstract}
The present study aimed to assess the drying kinetics of black rice and fit different mathematical models (empirical and diffusive) to the experimental data, and evaluate the effect of drying air temperature on the physical-chemical and bioactive compounds quality of black rice. Drying air temperatures ranged from 40 to 80 ${ }^{\circ} \mathrm{C}$ and the drying air speed was $1.5 \mathrm{~m} / \mathrm{s}$. Physical-chemical characterization of the product was based on the following parameters: moisture, water activity, ashes, total protein content, $\mathrm{pH}$, total acidity, lipids, total carbohydrates, total anthocyanins, flavonoids, total phenolic compounds and antioxidant activity. Among the empirical models, Page showed the lowest mean squared deviations (MSD) and highest coefficients of determination $\left(\mathrm{R}^{2}\right)$. For the diffusion model, the values of effective mass diffusivity and convective heat transfer coefficient increased with increasing drying air temperature, and the Biot number indicated that the first-type boundary condition would also describe well the drying process. Physical-chemical parameters and bioactive compounds differed between the temperatures used, and the temperature of $60{ }^{\circ} \mathrm{C}$ led to the best relationship between drying time and preservation of product characteristics.
\end{abstract}

Keywords: bioactive compounds, diffusivity, grains, quality

\section{Introduction}

Rice (Oryza sativa L.) is considered a staple food by a significant part of the world's population (Papillo et al., 2018). In the last years, grains of pigmented rice, such as black rice, have gained attention because this type of rice has benefits to health, due to bioactive pigments located in its bran layer, which contains higher content of phenolic compounds (Paiva et al., 2014; Vargas et al., 2018). In addition to $\gamma$-oryzodiol and vitamin C, there are also some water-soluble pigments which are responsible for its color and antioxidant properties (Hou et al., 2013; Norkaew et al., 2017). Black rice also contains a higher lipid content than non-pigmented and red rice, which makes it more palatable and attractive (Choi et al., 2019).

According to Ding et al. (2018), the enzymatic activity may increase and accelerate lipid degradation during storage, in addition to reducing the sensory quality of rice. Therefore, post-harvest techniques such as the drying process, which involves the reduction of seed moisture content to a safe level, can be applied to guarantee the preservation of physiological and physical-chemical quality of the product to be stored during a long period of time (Sousa et al., 2016). However, many of the properties of agricultural products are affected by the drying conditions (Dehghannya et al., 2016).

According to Silva et al. (2018), through the drying kinetics it is possible to determine the behavior of the dried material, representing it by drying curves and drying rates (Menezes et al., 2013). Several mathematical models have been used to describe the drying process of agricultural products and to determine process information which can be used in future equipment designs (Meneghetti et al., 2012). Under certain conditions (spherical or cylindrical geometries, infinite slabs and constant thermal-physical parameters and volume), the diffusion equation has an analytical solution (Luikov, 1968; Crank, 1992). These solutions are used to describe the thin-layer drying of various agricultural products, besides determining the effective mass flow diffusivity and convective mass transfer coefficient (Silva et al., 2010). 
Therefore, the present study aimed to assess the drying kinetics of black rice at different drying air temperatures, fitting different mathematical models to the experimental data as a function of the moisture content, obtain the effective mass diffusivity from the analytical solution of the diffusion equation with third-type boundary condition considering the cylindrical geometry, besides characterizing and evaluating the effect of drying air temperature on the physical-chemical and bioactive compounds quality of black rice.

\section{Material and Methods}

\subsection{Research Site and Acquisition of Grains}

The study was conducted in the Laboratory of Storage and Processing of Agricultural Products (LAPPA) of the Federal University of Campina Grande (UFCG), Campus of Campina Grande, Paraíba (PB), Brazil. Black rice grains were purchased in a local store of the city of Campina Grande-PB, and then visually selected for sampling uniformity.

\subsection{Drying Kinetics}

Black rice grains were dried in triplicate in a forced air circulation oven regulated to operate at temperatures of $40,50,60,70$ and $80{ }^{\circ} \mathrm{C}$, with air speed of $1.5 \mathrm{~m} / \mathrm{s}$. Samples were uniformly distributed on steel screen trays, forming a thin layer (Figure 1).

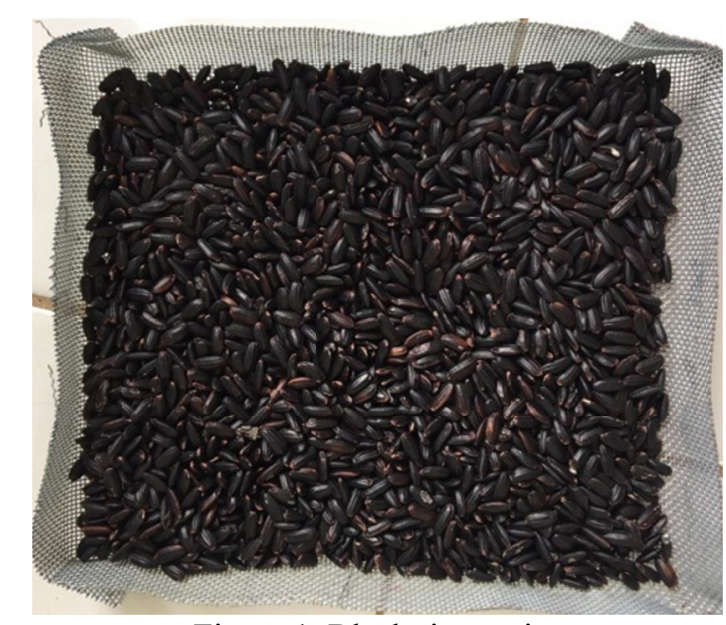

Figure 1. Black rice grains

The experimental data were expressed in terms of moisture content ratio (RX), given by the relationship between the differences in moisture content over time, $t$, and the equilibrium moisture content $(\mathrm{X}-\mathrm{Xe})$ and the initial and equilibrium moisture contents $\left(\mathrm{X}_{0}-\mathrm{Xe}\right)$, as described in Equation (1),

$$
R X=\frac{\left(X-X_{e}\right)}{\left(X_{0}-X_{e}\right)}
$$

where, $R X=$ moisture content ratio (dimensionless); $X_{e}=$ equilibrium moisture content (dry basis); $X=$ moisture content (dry basis); $X_{o}=$ initial moisture content (dry basis).

Three empirical models (with up to three parameters) were fitted to the values observed for each drying air temperature (Table 1), by the Quasi-Newton method, using the program Statistica 7.0 (Statsoft Co, 2007).

Table 1. Empirical models used to predict the drying phenomenon of black rice

\begin{tabular}{ll}
\hline Models & Equation \\
\hline Page & $\mathrm{RX}=\exp \left(-\mathrm{k} \cdot \mathrm{t}^{\mathrm{n}}\right)$ \\
Henderson \& Pabis & $\mathrm{RX}=\mathrm{a} \cdot \exp (-\mathrm{k} \cdot \mathrm{t})$ \\
Parry & $\mathrm{RX}=\mathrm{a} \cdot \exp (-\mathrm{k} \cdot \mathrm{t})+\mathrm{c}$ \\
\hline
\end{tabular}

Note. t: drying time (min); k: drying constant; a, c, n: coefficients of the models. 
The fitting of each model was evaluated based on the coefficient of determination $\left(\mathrm{R}^{2}\right)$ and Mean Squared Deviation (MSD), calculated by Equation (2):

$$
M S D=\sqrt{\frac{\left(R X_{\exp }-R X_{p r e}\right)^{2}}{N}}
$$

where, $R X_{\text {exp }}=$ moisture content ratio (dimensionless moisture content) obtained experimentally; $R X_{\text {pre }}=$ moisture content ratio predicted by the mathematical model; $N=$ number of observations along the drying kinetics.

\subsection{Diffusion Equation}

The diffusion equation which describes the drying of a product in the form of an infinite cylinder can be written for the dimensionless moisture content as:

$$
\frac{\partial R X}{\partial t}=\frac{1}{r} \frac{\partial}{\partial r}\left(r D \frac{\partial R X}{\partial r}\right)
$$

where, $D$ is the effective mass diffusivity and $\mathrm{r}$ defines a position inside the cylinder relative to its axial axis. Since RX is the moisture ratio, it should be noted that its initial value is 1 and the equilibrium value is zero. In the present study, an analytical solution of Equation (3) was used to describe moisture diffusion in cylindrical bodies.

\subsection{Analytical Solution for the Convective Boundary Condition}

The third-type boundary condition, or the Cauchy boundary condition, is expressed by the imposition of equal internal diffusive flow at the limit of the infinite cylinder and external convective flow close to this limit, given by Equation (4),

$$
-\left.D \frac{\partial R X(r, t)}{\partial r}\right|_{r=R}=\left.h R X(r, t)\right|_{r=R}
$$

where, $h$ is the convective transfer coefficient; $R X(r, t)$ is the moisture ratio at the radial position $r$ and time $t$; and $R$ is the radius of the infinite cylinder.

The average moisture ratio for a cylindrical solid at time $\mathrm{t}$ is given, for the first 16 terms of the series (rather than infinite terms), by (Luikov, 1968; Crank, 1992),

$$
R X(t)=\sum_{n=1}^{16} B_{n} \exp \left(-\mu_{n}^{2} \frac{D}{R^{2}} t\right)
$$

where, the parameter $B_{n}$ is given by,

$$
B_{n}=\frac{4 B i^{2}}{\mu_{n}^{2}\left(B i^{2}+\mu_{n}^{2}\right)}
$$

where, $\mathrm{Bi}$ is the Biot number, given by,

$$
B i=\frac{h R}{D}
$$

where, $h$ is the convective mass transfer coefficient; $R$ is the cylinder radius; $D$ is the effective mass diffusivity. In Equation 6, $\mu_{n}$ represents the roots of the transcendental equation,

$$
\frac{J_{0}\left(\mu_{n}\right)}{J_{1}\left(\mu_{n}\right)}=\frac{\mu_{n}}{B i}
$$

where, $J_{0}$ is the first-type zero-order Bessel function and $\mathrm{J}_{1}$ is the first-type first-order Bessel function.

To obtain the analytical solution, the process was optimized using the program "Convective" (F. A. S. Silva \& C. A. V. Silva, 2008). The program Convective is used to study water diffusion processes with known experimental data, for the following geometries: infinite slab, infinite cylinder, sphere, finite cylinder and parallelepiped. 


\subsection{Physical-Chemical and Bioactive Compounds Characterization of Fresh and Dehydrated Grains}

Black rice grains, both fresh and after each drying process, were characterized for physical-chemical parameters and bioactive compounds based on: moisture content, determined by drying in oven at $105{ }^{\circ} \mathrm{C}$ until constant weight; water activity (Aw), determined using a Decagon ${ }^{\circledR}$ Aqualab CX-2T device at $25^{\circ} \mathrm{C}$; ashes, determined by incineration in muffle furnace; total protein content, quantified by the Micro-Kjeldahl method, which consisted in determining total nitrogen and converting the result into protein using the 5.95 factor, recommended for cereal proteins, according to the methodology described by Brasil (2008); $\mathrm{pH}$, determined by direct reading in a digital pH meter; total acidity, determined by titrimetry, according to Brasil (2008); and lipids, determined by the method of Bligh and Dyer (1959). The total carbohydrate content was calculated by difference to obtain $100 \%$ of the total composition (FAO, 2003).

The contents of total anthocyanins and flavonoids were determined by the single $\mathrm{pH}$ method described by Francis (1982). This method consists in a quantitative transfer of an aliquot of the concentrated extract to a container and, subsequently, diluting this aliquot in a quantity of Ethanol- $\mathrm{HCl}$ at $1.5 \mathrm{~mol} \mathrm{~L}^{-1}$, thus creating a diluted volume of extract. Total phenolic compounds were quantified by the Folin-Ciocalteau method described by Waterhouse (2006), using gallic acid as standard. The calculations performed to determine the phenolic compounds were based on a standard curve of gallic acid, and the readings were taken in spectrophotometer at $765 \mathrm{~nm}$, with the results expressed in $\mathrm{mg} 100 \mathrm{~g}^{-1}$ of gallic acid equivalent. Antioxidant activity was determined using the method proposed by Re et al. (1999), with modifications made by Rufino et al. (2007).

\subsection{Statistical Analysis}

The experimental data were analyzed in triplicate and the results were subjected to single-factor analysis of variance (ANOVA) at 0.05 probability level, and the significant qualitative responses were subjected to Tukey test also at 0.05 probability level. All statistical analyses were carried out using the program Assistat 7.7 (Silva \& Azevedo, 2016).

\section{Results and Discussion}

It is interesting to observe that temperatures above $70{ }^{\circ} \mathrm{C}$ caused cracks in the grains. On the other hand, the drying time decreased proportionally to the increase in drying air temperature, ranging from 450 to 810 minutes, which were respectively found at the temperatures of 80 and $40{ }^{\circ} \mathrm{C}$. Such behavior occurs because the highest rates of water removal from the product occur at the highest temperatures, which consequently reduces the drying time. Table 2 presents the values obtained for the fitting parameters of the drying kinetics and it can be observed that for Page, Henderson and Pabis and Parry models, the drying constant $(\mathrm{k})$ increased with the drying temperature. For these same models, the parameters "a" and " $n$ " were not influenced by the temperature, but for Parry model, like the drying constant (k), the parameter "c" was influenced by the temperature, showing direct relationship with the increase in temperature.

It can be observed that all models showed coefficients of determination $\left(R^{2}\right)$ above $98 \%$, but only the coefficients higher than $99 \%$ were considered as satisfactory fits. Therefore, the mathematical model of Page had high values of coefficient of determination $\left(\mathrm{R}^{2}\right)$ at all drying temperatures, ranging from $0.99665\left(40{ }^{\circ} \mathrm{C}\right)$ to $0.99904\left(80^{\circ} \mathrm{C}\right)$. The mean squared deviation (MSD) varied from 0.01291 to 0.04495 , but the mathematical model which showed the lowest and best values was the Page model, which obtained MSD from $0.01291\left(80^{\circ} \mathrm{C}\right)$ to $0.03227\left(40{ }^{\circ} \mathrm{C}\right)$. Lang et al. (2018) studied the drying kinetics of black rice using fixed-bed dryer with air speed of $0.5 \mathrm{~m} / \mathrm{s}$ and also concluded that the Page model was the best one to describe the drying kinetics. 
Table 2. Fitting parameters of drying kinetics of black rice, coefficient of determination $\left(\mathrm{R}^{2}\right)$, and mean squared deviation (MSD) for the mathematical models at the temperatures of $40,50,60,70$ and $80{ }^{\circ} \mathrm{C}$

\begin{tabular}{|c|c|c|c|c|c|c|c|}
\hline \multirow{2}{*}{ Models } & \multirow{2}{*}{$\mathrm{T}\left({ }^{\circ} \mathrm{C}\right)$} & \multicolumn{4}{|c|}{ Fitting parameters } & \multirow{2}{*}{$\mathrm{R}^{2}$} & \multirow{2}{*}{ MSD } \\
\hline & & $\mathrm{a}$ & $\mathrm{k}$ & $\mathrm{n}$ & $\mathrm{c}$ & & \\
\hline \multirow{5}{*}{ Page } & 40 & - & 0.023707 & 0.73426 & - & 0.99665 & 0.03227 \\
\hline & 50 & - & 0.032730 & 0.70469 & - & 0.99769 & 0.02159 \\
\hline & 60 & - & 0.035665 & 0.70877 & - & 0.99785 & 0.02041 \\
\hline & 70 & - & 0.051316 & 0.68219 & - & 0.99844 & 0.01701 \\
\hline & 80 & - & 0.067378 & 0.65819 & - & 0.99904 & 0.01291 \\
\hline \multirow{5}{*}{ Henderson \& Pabis } & 40 & 0.88710 & 0.00496 & - & - & 0.99526 & 0.04495 \\
\hline & 50 & 0.87478 & 0.00627 & - & - & 0.99388 & 0.03513 \\
\hline & 60 & 0.87921 & 0.00745 & - & - & 0.99279 & 0.03735 \\
\hline & 70 & 0.87795 & 0.01087 & - & - & 0.98785 & 0.04740 \\
\hline & 80 & 0.87156 & 0.01406 & - & - & 0.98562 & 0.04974 \\
\hline \multirow{5}{*}{ Parry } & 40 & 0.884314 & 0.00502 & - & 0.00386 & 0.99527 & 0.04482 \\
\hline & 50 & 0.858236 & 0.00683 & - & 0.02446 & 0.99429 & 0.03394 \\
\hline & 60 & 0.860448 & 0.00818 & - & 0.02789 & 0.99330 & 0.03602 \\
\hline & 70 & 0.850637 & 0.01296 & - & 0.04813 & 0.99019 & 0.04262 \\
\hline & 80 & 0.841938 & 0.01726 & - & 0.05582 & 0.98929 & 0.04275 \\
\hline
\end{tabular}

Among the models analyzed, Page model fitted best to the experimental data because it showed highest values of coefficient of determination $\mathrm{R}^{2}(>0.99665)$ and lowest values of $\mathrm{MSD}(<0.0322)$ for the studied temperatures (Figure 2).

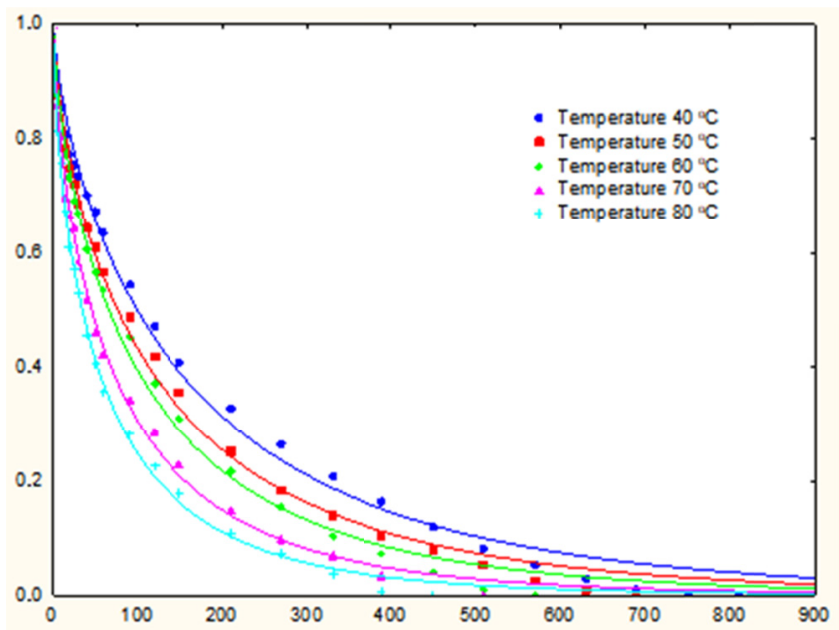

Figure 2. Drying curves (dimensionless moisture content versus time in minutes) of black rice grains determined by the Page model at temperatures of $40,50,60,70$ and $80^{\circ} \mathrm{C}$

Since the average value of the radius of the rice grains was $1.73 \mathrm{~mm}$, the values of effective mass diffusivity were calculated (Table 3), and these values increased from 2.24 to $5.21 \times 10^{-9} \mathrm{~m}^{2} \mathrm{~min}^{-1}$ when the drying air temperature increased from $40{ }^{\circ} \mathrm{C}$ to $80{ }^{\circ} \mathrm{C}$. This phenomenon also occurred for the convective heat transfer coefficient, which increased from 3.75 to $60.8 \times 10^{-5} \mathrm{~m} \mathrm{~min}^{-1}$. The Biot number did not show direct relationship with the increase of temperature, since the highest number was obtained at the temperature of $80{ }^{\circ} \mathrm{C}$, indicating that the first-type boundary condition would also describe well the drying process. 
Table 3. Results obtained by optimization using the analytical solution

\begin{tabular}{llll}
\hline Temperature $\left({ }^{\circ} \mathrm{C}\right)$ & $\left(\mathrm{D}_{\text {ef }} \times 10^{9} \mathrm{~m}^{2} \mathrm{~min}^{-1}\right)$ & $\left(\mathrm{h} \times 10^{5} \mathrm{~m} \mathrm{~min}^{-1}\right)$ & Biot Number \\
\hline 40 & 2.24 & 3.75 & 29 \\
50 & 2.75 & 7.65 & 50 \\
60 & 3.14 & 7.82 & 42 \\
70 & 4.62 & 19.9 & 77.5 \\
80 & 5.21 & 60.8 & 200 \\
\hline
\end{tabular}

According to Lang et al. (2018), diffusivity corresponds to the magnitudes of the drying rates affected by the drying temperature. Thus, the highest drying rates showed the highest values of diffusivity. Silva et al. (2014), evaluating the diffusivity of pigeon pea grains at temperatures from 40 to $70{ }^{\circ} \mathrm{C}$, found values ranging from 2.1 to $6.8 \times 10^{-10} \mathrm{~m}^{2} \mathrm{~s}^{-1}$. For red rice grains, Sousa et al. (2016) obtained values which varied from 2.33 to $6.45 \times$ $10^{-11} \mathrm{~m}^{2} \mathrm{~s}^{-1}$.

However, the higher the value of diffusivity, the higher the facility for water molecules to be removed from the product, causing water to be more bound to the molecules constituting the dry mass. High values of heat transfer coefficient tend to lead to shorter time to reach equilibrium moisture. Johann et al. (2015) in studies with the thin-layer drying of grape grains at temperatures from 50 to $80^{\circ} \mathrm{C}$, obtained convective heat transfer coefficients from 4.11 to $21.54 \times 10^{-5} \mathrm{~m} \mathrm{~min}^{-1}$.

The results obtained in the characterization physical-chemical parameters and bioactive compounds of black rice grains before the drying process are described in Table 4.

Table 4. Physical-chemical and bioactive characterization of black rice grains before drying

\begin{tabular}{|c|c|}
\hline Parameters & Mean and Standard deviation \\
\hline Moisture (\%, w.b. $)^{1}$ & $12.75 \pm 0.63$ \\
\hline Water activity $\left(\mathrm{A}_{\mathrm{w}}\right)$ & $0.648 \pm 0.02$ \\
\hline $\mathrm{pH}$ & $6.50 \pm 0.07$ \\
\hline Total acidity $(\%)$ & $0.030 \pm 0.01$ \\
\hline Ashes $(\%)$ & $1.97 \pm 0.15$ \\
\hline Proteins (\%) & $8.66 \pm 0.12$ \\
\hline Lipids (\%) & $2.93 \pm 0.06$ \\
\hline Carbohydrates (\%) & $73.69 \pm 0.30$ \\
\hline Total anthocyanins (mg $\left.100 \mathrm{~g}^{-1}\right)$ & $70.20 \pm 0.69$ \\
\hline Flavonoids (mg $100 \mathrm{~g}^{-1}$ ) & $38.48 \pm 0.84$ \\
\hline Total phenolic compounds (mg GAE $100 \mathrm{~g}^{-1}$ ) & $289.93 \pm 1.12$ \\
\hline Antioxidant activity $^{2}\left(\mu \mathrm{mol}\right.$ Trolox $\left.\mathrm{g}^{-1}\right)$ & $209.20 \pm 0.98$ \\
\hline
\end{tabular}

Note. ${ }^{1}$ wet basis. ${ }^{2} \mathrm{ABTS}^{+}$.

The black rice showed moisture content of (12.75\%), which is close to the value found by Ziegler et al. (2017) for black rice (13.7\%) and higher than the value found by Becker-algeri et al. (2017) for whole rice (10.7\%). According to Matos (2014), pigmented rice grains tend to show different characteristics from those of non-pigmented rice, such as higher contents of moisture and protein. In addition, water activity in the present study was 0.648 , which characterizes the grains as of intermediate moisture. Oliveira (2016) classifies as products of intermediate moisture those which have water activity between 0.6 and 0.85 .

Similar values of $\mathrm{pH}(6.67)$ and total acidity (0.05\%) were verified by Alencar et al. (2017), characterizing black rice grains. For ash content, Marquez (2013) obtained values between 1.5 and $1.8 \%$ in black rice grains and between 1.3 and $1.7 \%$ in red rice grains, but the ash contents considering both types of pigmentation were similar to those found in the present study.

Based on the values of proteins, lipids and carbohydrates, as observed in Table 4, black rice grains can be considered as of high protein content, with value close to those found also in black rice by Paiva et al. (2014) and Ziegler et al. (2017), respectively $8 \%$ and $9.8 \%$. Ziegler et al. (2017), also evaluating lipid and carbohydrate contents in black rice grains, obtained higher lipid content (4.4\%) than that of the present study and lower 
carbohydrate content (70.5\%), but also close to the one found in the present study, thus demonstrating that black rice grains are highly rich in total fibers, since the analysis of total carbohydrate includes the contents of fiber.

The content of total anthocyanins was $\left(70.2 \mathrm{mg} 100 \mathrm{~g}^{-1}\right)$ and that of flavonoids was $\left(38.38 \mathrm{mg} 100 \mathrm{~g} \mathrm{~g}^{-1}\right)$. Abdel-Aal et al. (2018) studied purple wheat grains and obtained a variation of $13.7-57.4 \mathrm{mg} 100 \mathrm{~g}^{-1}$ for anthocyanin contents, evidencing the technological potential of black rice grains.

Black rice grains had phenolic compounds content of (289.93 mg GAE $\left.100 \mathrm{~g}^{-1}\right)$ and antioxidant activity of $\left(209.20 \mu \mathrm{mol}\right.$ Trolox $\left.\mathrm{g}^{-1}\right)$. These values of total phenolic compounds were similar to those found by Min et al. (2012) (240 to $540 \mathrm{mg}$ GAE $100 \mathrm{~g}^{-1}$ ) and lower than those reported by Chen et al. (2012) (400 to $650 \mathrm{mg}$ GAE $100 \mathrm{~g}^{-1}$ ), both for black rice grains. However, these variations may be related to differences in grain cultivation and extraction methods. The results obtained in the present study demonstrate that black rice grains have significant contents of total phenolic compounds with high antioxidant activity.

According to Braga (2013), quality parameters undergo changes during the drying process. Drying with hot air leads to reduction in nutritional values, besides altering texture, color and causing a slow or incomplete dehydration of the material (Nascimento et al., 2018). The results of physical-chemical and bioactive analyses at drying air temperatures of $40,50,60,70$ and $80^{\circ} \mathrm{C}$ are presented in Table 5.

Table 5. Physical-chemical and bioactive characterization of black rice grains after each drying process

\begin{tabular}{|c|c|c|c|c|c|}
\hline \multirow{2}{*}{ Parameters } & \multicolumn{5}{|c|}{ Drying temperatures } \\
\hline & $40^{\circ} \mathrm{C}$ & $50^{\circ} \mathrm{C}$ & $60^{\circ} \mathrm{C}$ & $70^{\circ} \mathrm{C}$ & $80^{\circ} \mathrm{C}$ \\
\hline Moisture (\% w.b.) & $11.55 \mathrm{a}$ & $8.17 \mathrm{~b}$ & $6.54 \mathrm{c}$ & $4.68 \mathrm{~d}$ & $3.23 \mathrm{e}$ \\
\hline Water activity $\left(\mathrm{A}_{\mathrm{w}}\right)$ & $0.321 \mathrm{a}$ & $0.183 \mathrm{~b}$ & $0.165 \mathrm{c}$ & $0.156 \mathrm{~d}$ & $0.121 \mathrm{e}$ \\
\hline $\mathrm{pH}$ & $6.69 \mathrm{~b}$ & $6.70 \mathrm{ab}$ & $6.72 \mathrm{a}$ & $6.70 \mathrm{ab}$ & $6.70 \mathrm{ab}$ \\
\hline Total acidity $(\%)$ & $0.029 \mathrm{a}$ & $0.027 \mathrm{a}$ & $0.028 \mathrm{a}$ & $0.028 \mathrm{a}$ & $0.029 \mathrm{a}$ \\
\hline Ashes (\%) & $3.83 \mathrm{~d}$ & $4.64 \mathrm{c}$ & $5.68 \mathrm{~b}$ & $6.51 \mathrm{a}$ & $6.88 \mathrm{a}$ \\
\hline Proteins (\%) & $7.35 \mathrm{a}$ & $6.99 \mathrm{a}$ & $5.87 \mathrm{~b}$ & $4.67 \mathrm{c}$ & $3.21 \mathrm{~d}$ \\
\hline Lipids (\%) & $2.95 \mathrm{~d}$ & $3.05 \mathrm{~d}$ & $3.22 \mathrm{c}$ & $3.61 \mathrm{~b}$ & $3.89 \mathrm{a}$ \\
\hline Carbohydrates (\%) & $74.32 \mathrm{e}$ & $77.15 \mathrm{~d}$ & $78.69 \mathrm{c}$ & $80.53 \mathrm{~b}$ & $82.79 \mathrm{a}$ \\
\hline Anthocyanins (mg $100 \mathrm{~g}^{-1}$ ) & $67.19 \mathrm{a}$ & $65.62 \mathrm{~b}$ & $64.33 \mathrm{c}$ & $63.19 \mathrm{~d}$ & $62.01 \mathrm{e}$ \\
\hline Flavonoids (mg $100 \mathrm{~g}^{-1}$ ) & $29.98 \mathrm{a}$ & $29.66 \mathrm{~b}$ & $29.42 \mathrm{c}$ & $29.29 \mathrm{~d}$ & $29.14 \mathrm{e}$ \\
\hline Total phenolic compounds (mg GAE $100 \mathrm{~g}^{-1}$ ) & $268.55 \mathrm{a}$ & $258.87 \mathrm{~b}$ & $244.23 \mathrm{c}$ & $233.67 \mathrm{~d}$ & $231.14 \mathrm{~d}$ \\
\hline Antioxidant activity ${ }^{2}\left(\mu \mathrm{mol}\right.$ Trolox $\left.\mathrm{g}^{-1}\right)$ & $178.80 \mathrm{a}$ & $142.16 \mathrm{~b}$ & $117.12 \mathrm{c}$ & $73.32 \mathrm{~d}$ & $50.92 \mathrm{e}$ \\
\hline
\end{tabular}

Note. Equal lowercase letters in the same row do not differ significantly between the studied temperatures by Tukey test at 0.05 probability level. ${ }^{1}$ wet basis. ${ }^{2} \mathrm{ABTS}^{+}$.

There was a clear reduction in the moisture content of black rice grains as the temperature increased, which was expected because free water evaporated as the grains were subjected to heat, with variation from $11.55\left(40^{\circ} \mathrm{C}\right)$ to $3.23\left(80^{\circ} \mathrm{C}\right)$. This same parameter shows significant statistical difference when its values are compared between the different drying temperatures. In order to ensure the time of preservation and guarantee quality, it is necessary to know the water activity. In black rice grains, its behavior was similar to that of moisture contents, showing significant difference, with highest value $(0.321)$ for the temperature of $40^{\circ} \mathrm{C}$ and lowest value $(0.121)$ for the temperature of $80^{\circ} \mathrm{C}$.

The values obtained for $\mathrm{pH}$ are close to neutrality $(\mathrm{pH}=7.00)$ and ranged between 6.60 and 6.72 . Significant statistical difference in $\mathrm{pH}$ values was observed between the temperatures of 40 and $60{ }^{\circ} \mathrm{C}$, but there was no statistical difference between the temperatures of 50,70 and $80{ }^{\circ} \mathrm{C}$ at 0.05 probability level. For total acidity, the values obtained for all temperatures did not differ significantly; there was a small variation of up to $0.002 \%$ between treatments, with no influence of temperature on this parameter.

The ash contents did not differ significantly between the temperatures of 70 and $80{ }^{\circ} \mathrm{C}$. Its increase was proportional to the increase of temperature, and the sample subjected to drying at $80^{\circ} \mathrm{C}$ had the largest amount of ashes (6.88\%). By comparing the ash contents in fresh grains (Table 4) and in dehydrated grains (Table 5), it was possible to note a $4.91 \%$ gain of mineral salts. However, the opposite was observed in the protein content, where the increase of temperature led to protein degradation; grains subjected to temperatures of 40 and $50{ }^{\circ} \mathrm{C}$ did not 
differ statistically, but those dried at 60,70 and $80{ }^{\circ} \mathrm{C}$ were statistically different at 0.05 probability level. Consequently, the lowest protein content was obtained in grains subjected to drying at $80^{\circ} \mathrm{C}(3.21 \%)$, showing a reduction of $5.45 \%$ compared to grains not subjected to the drying process.

The same pattern observed for ash content occurred for lipid content but, as the drying temperature increased, there was a slight increase of lipid content in the grains. According to Table 5, there was no difference between the drying temperatures of 40 and $50{ }^{\circ} \mathrm{C}$ but, as the temperature increased, there was an increase of up to $0.96 \%$ in the lipid content of the grains, compared to those presented in Table 4. Carbohydrates were determined by difference based on the other constituents and, therefore, the reduction of moisture automatically led to an increase of up to $8.47 \%$ in carbohydrate content between the applied temperatures. Nevertheless, the values obtained for each treatment were significantly different from one another.

In relation to the contents of anthocyanins and flavonoids, there was significant difference between the

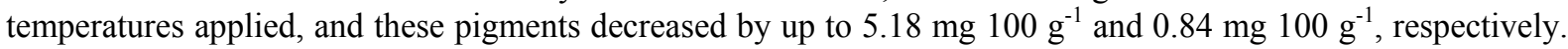
According to Modesto Júnior et al. (2016), several factors interfere with anthocyanin stability, including $\mathrm{pH}$, action of oxygen, enzymes, temperature variation and light incidence.

The contents of total phenolic compounds in the grains did not differ significantly between the drying temperatures of 70 and $80^{\circ} \mathrm{C}$, but differed from those found in grains subjected to temperatures of 40,50 and 60 ${ }^{\circ} \mathrm{C}$. This parameter varied from 231.14 to $268.55 \mathrm{mg} \mathrm{GAE} 100 \mathrm{~g}^{-1}$ and these values were respectively found at temperatures of 80 and $40^{\circ} \mathrm{C}$.

For antioxidant activity, it can be observed that the different temperatures applied led to degradation of antioxidant compounds, which, for being unstable natural compounds, underwent significant alterations. The antioxidant activity of black rice grains decreased as the drying air temperature increased, and there was a reduction of up to $158.91 \mu \mathrm{mol}$ Trolox. $\mathrm{g}^{-1}$ at the temperature of $60{ }^{\circ} \mathrm{C}$, compared to the antioxidant activity of fresh grains (Table 4).

\section{Conclusion}

The study on the drying kinetics of black rice demonstrated that increasing temperature led to reduction in drying time, and temperatures above $70{ }^{\circ} \mathrm{C}$ caused cracks in the grains. In the fitting of mathematical models to the experimental data, as a function of moisture content, the Page model showed the lowest values of MSD and highest coefficients of determination $\left(\mathrm{R}^{2}\right)$. Obtaining the results of the diffusion equation by optimization through an analytical solution allowed observing that the highest values of diffusivity and convective heat transfer coefficient occurred at the temperature of $80{ }^{\circ} \mathrm{C}$, indicating higher facility for water molecules to be removed from the grains. The Biot number indicated that the first-type boundary condition would also describe well the drying process. There was a significant difference between the temperatures used with respect to the physical-chemical parameters and bioactive compounds, and the temperature of $60{ }^{\circ} \mathrm{C}$ led to the best relationship between drying time and preservation of the characteristics of black rice grains.

\section{References}

Abdel-Aal, E. S. M., Hucl, P., \& Rabalski, I. (2018). Compositional and antioxidant properties of anthocyanin-rich products prepared from purple wheat. Food Chemistry, 254, 13-19. https://doi.org/ 10.1016/j.foodchem.2018.01.170

Alencar, D. D. O, Moura, H. V., Gusmão, R. P., \& Gusmão, T. A. S. (2017). Physical-chemical and granulometric characterization of black rice flour. Revista Higiêne Alimentar, 31, 1415-1417.

Becker-Algeri, T. A., Mendes, G. L., Colli, R., Grilo, B. C., \& Furlong, E. B. (2017). Efeito do beneficiamento e aplicação de tratamento térmico na composição química e digestibilidade proteica do arroz. Revista do Congresso Sul Brasileiro de Engenharia de Alimentos, 3(1).

Bligh, E. G., \& Dyer, W. J. (1959). A rapid method of total lipid extraction and purification. Canadian Journal Biochemistry Physiology, 37, 911-917. https://doi.org/10.1139/y59-099

Braga, T. R., Pereira, R. C. A., Silveira, M. R. S., Silva, L. R., Silva, A. R., \& Oliveira, M. M. T. (2013). Caracterização físico-química de progênies de pimentas (Capsicum frutescens L.). Revista de la Facultad de Agronomía, 112, 6-10.

Brasil, Instituto Adolfo Lutz. (2008). Métodos fisico-quimicos para análise de alimentos (4th ed., Volume 1, p. 1020). São Paulo: Instituto Adolfo Lutz. 
Chen, X. Q., Nagao, N., Itani, T., Irifune, K. (2012). Anti-oxidative analysis, and identification and quantification of anthocyanin pigments in different coloured rice. Food Chemistry, 135, 2783-2788. https://doi.org/10.1016/j.foodchem.2012.06.098

Choi, S., Seo, H. S., Lee, K. R., Lee, S., \& Lee, J. (2019). Effect of milling and long-term storage on volatiles of black rice (Oryza sativa L.) determined by headspace solid-phase microextraction with gas chromatography-mass spectrometry. Food Chemistry, 276, 572-582. https://doi.org/10.1016/j.foodchem. 2018.10.052

Crank, J. (1992). The Mathematics of Diffusion. Clarendon Press, Oxford, UK.

Dehghannya, J., Gorbani, R., \& Ghanbarzadeh, B. (2016). Shrinkage of Mirabelle Plum during Hot Air Drying as Influenced by Ultrasound-Assisted Osmotic Dehydration. International Journal of Food Properties, 19(5), 1093-1103. https://doi.org/10.1080/10942912.2015.1055362

Ding, C., Khir, R., Pan, Z., Wood, D. F., Venkitasamy, C., Tu, K., El-Mashad, H., \& Berrios, J. (2018). Influence of infrared drying on storage characteristics of brown rice. Food Chemistry, 264, 149-156. https://doi.org/10.1016/j.foodchem.2018.05.042

FAO (Food and Agriculture Organization of the United Nations). (2003). Food Energy: Methods of Analysis and Conversion Factors. Report of a Technical Workshop; Food and Nutrition Paper Volume 77; FAO: Rome, Italy.

Francis, F. J. (1982). Analysis of anthocyanins in foods. In P. Markakis (Ed.), Anthocyanins as Food Colors (pp. 181-207). New York, Academic Press. https://doi.org/10.1016/B978-0-12-472550-8.50011-1

Hou, Z., Qin, P., Zhang, Y., Cui, S., \& Ren, G. (2013). Identification of anthocyanins isolated from black rice (Oryza sativa L.) and their degradation kinetics. Food Research International, 50(2), 691-697. https://doi.org/10.1016/j.foodres.2011.07.037

Johann, G., Pereira, N. C., Silva, E. A. (2015). Avaliação de modelo matemático de parâmetros distribuídos aplicado à secagem de grãos de uva em camada fina. Blucher Chemical Engineering Proceedings, 2(1), 521-530.

Lang, G. H., Lindemann, I. D. S., Ferreira, C. D., Pohndorf, R. S., Vanier, N. L., \& de Oliveira, M. (2018). Influence of drying temperature on the structural and cooking quality properties of black rice. Cereal Chemistry, 95(4), 564-574. https://doi.org/10.1002/cche.10060

Luikov, A. V. (1968). Analytical Heat Diffusion Theory. Academic Press, Inc., Ltd., London.

Massaretto, I. L. (2013). Características químicas e nutricionais de arroz-preto, vermelho e selvagem e comparação por análise estatística multivariada (Tese de Doutorado, Universidade de São Paulo, São Paulo, Brasil). https://doi.org/10.11606/T.9.2013.tde-04062014-152239

Matos, A. D. (2014). Avaliação bioquímica nutricional de cultivares de arroz (Dissertação de Mestrado, Universidade do Vale do Rio dos Sinos, São Leopoldo, Brasil).

Meneghetti, V. L., Aosani, E., da Rocha, J. C., de Oliveira, M., Elias, M. C., \& Pohndorf, R. S. (2012). Modelos matemáticos para a secagem intermitente de arroz em casca. Revista Brasileira de Engenharia Agricola e Ambiental, 16(10), 1115-1120. https://doi.org/10.1590/S1415-43662012001000012

Menezes, M. L., A. P., Ströher, N. C. Pereira., \& Barros, S. T. D. (2013). Análise da cinética e ajustes de modelos matemáticos aos dados de secagem do bagaço do maracujá-amarelo. Revista Engevista, 15, 176-186. https://doi.org/10.22409/engevista.v15i2.443

Min, B., Gu, L., Mcclung, A. M., Bergman, C. J., \& Chen, M. (2012). Free and bound total phenolic concentrations, antioxidant capacities, and profiles of proanthocyanidinis and anthocyanins in whole grain rice (Oryza sativa L.) of different bran colours. Food Chemistry, 133, 715-722. https://doi.org/10.1016/ j.foodchem.2012.01.079

Modesto Júnior, E. N., da Silva Soares, S., Gomes, P. W. P., Ribeiro, C. D. F. A., \& da Silva, R. M. V. (2016). Estudo do armazenamento da polpa do fruto ginja Eugênia uniflora L. e sua influência nos teores de ácido ascórbico e antocianinas. Scientia Plena, 12(6).

Norkaew, O., Boontakham, P., Dumri, K., Noenplab, A. N. L., Sookwong, P., \& Mahatheeranont, S. (2017). Effect of post-harvest treatment on bioactive phytochemicals of Thai black rice. Food Chemistry, 217, 98-105. https://doi.org/10.1016/j.foodchem.2016.08.084 
Oliveira, C. F. D., Pinto, E. G., Tomé, A. C., Quintana, R. C., \& Dias, B. F. (2016) Desenvolvimento e caracterização de geleia de laranja enriquecida com aveia. Revista de Agricultura Neotropical, 3(3), $20-23$. https://doi.org/10.32404/rean.v3i3.1203

Paiva, F. F., Vanier, N. L., Berrios, J. D. J., Pan, J., de Almeida Villanova, F., Takeoka, G., \& Elias, M. C. (2014). Physicochemical and nutritional properties of pigmented rice subjected to different degrees of milling. Journal of Food Composition and Analysis, 35(1), 10-17. https://doi.org/10.1016/ j.jfca.2014.05.003

Papillo, V. A., Locatelli, M., Travaglia, F., Bordiga, M., Garino, C., Arlorio, M., \& Coïsson, J. D. (2018). Spray-dried polyphenolic extract from Italian black rice (Oryza sativa L., var. Artemide) as new ingredient for bakery products. Food Chemistry, 269, 603-609. https://doi.org/10.1016/j.foodchem.2018.07.059

Re, R., Pellegrini, N., Proteggente, A., Pannala, A., Yang, M., \& Rice-Evans, C. (1999). Antioxidant activity applying an improved ABTS radical cation decolorization assay. Free Radical Biology and Medicine, 26, 1231-1237.

Rufino, M. S. M., Alves, R. E., Brito, E. S., Morais, S. M., Sampaio, C. G., Jimenez, J. P., \& Calixto, F. D. S. (2007). Determinação da atividade antioxidante total em frutas pela captura do radical livre DPPH. Comunicado Técnico Embrapa, 127, 1-4.

Silva, F. A. S., \& Azevedo, C. A. V. (2016). The Assistat Software Version 7.7 and its use in the analysis of experimental data. African Journal Agricultural Research, 11, 3733-3740. https://doi.org/10.5897/AJAR 2016.11522

Silva, L. M. M., Sousa, F. C., Sousa, E. P., Cavalcanti-Mata, M. E. R. M., \& Duarte, M. E. M. (2014). Modelos de predição da cinética de secagem dos grãos de guandu. Brazilian Journal of Food Technology, 17(4), 310-318. https://doi.org/10.1590/1981-6723.3014

Silva, S. N., Matos, J. D. P., Silva, P. B., Costa, Z. R. T., Gomes, J. P., Silva, L. P. F. R., ... Alexandre, H. V. (2018). Prediction of Mathematical Models of the Drying Kinetics and Physicochemical Quality of the Chili Pepper. Journal of Agricultural Science, 10(12), 377-384. https://doi.org/10.5539/jas.v10n12p377

Silva, W. P., \& Silva, C. M. D. P. S. (2018). Convectivo Adsorção e Dessorção [Versão 3.2 (2008-2018)]. Retrieved from http://zeus.df.ufcg.edu.br/labfit/Convective.htm

Silva, W. P., Precker, J. W., Silva, C. M. D. P. S., \& Gomes, J. P. (2010). Determination of effective diffusivity and convective mass transfer coefficient for cylindrical solids via analytical solution and inverse method: Application to the drying of rough rice. Journal of Food Engineering, 98(3), 302-308. https://doi.org/ 10.1016/j.jfoodeng.2009.12.029

Sousa, R. V., Cavalcante-Mata, M. E. R. M., Duarte, M. E. M., Almeida, R. D., \& Roosa, M. E. C. (2016). Análise da cinética de secagem em camada fina do arroz vermelho em casca. Revista Brasileira de Produtos Agroindustriais, 18, 517-529. https://doi.org/10.15871/1517-8595/rbpa.v18nespp517-529

Statsoft. (2007). Statistics for Window-Computer program manual (Version 7.0). Tulsa: Statsoft Inc.

Vargas, C. G., da Silva Junior, J. D., Rabelo, T. K., Moreira, J. C. F., Gelain, D. P., Rodrigues, E., ... Flôres, S. H. (2018). Bioactive compounds and protective effect of red and black rice brans extracts in human neuron-like cells (SH-SY5Y). Food Research International, 113, 57-64. https://doi.org/10.1016/ j.foodres.2018.06.069

Waterhouse, A. (2006). Folin-ciocalteau micro method for total phenol in wine. American Journal of Enology and Viticulture, 3-5.

Ziegler, V., Ferreira, C. D., Tonieto, L., Silva, J. G., Oliveira, M., \& Elias, M. C. (2017). Effects of storage temperature of whole rice grains with brown, black and red pericarps, on the physicochemical and pasting properties. Brazilian Journal Food Technology, 20(e2016051).

\section{Copyrights}

Copyright for this article is retained by the author(s), with first publication rights granted to the journal.

This is an open-access article distributed under the terms and conditions of the Creative Commons Attribution license (http://creativecommons.org/licenses/by/4.0/). 